\title{
EFFECT OF PLANT DENSITIES AND POTASSIUM FERTILIZATION RATES ON YIELD AND QUALITY OF SUGAR BEET CROP IN SANDY RECLAIMED SOILS. (Beta vulgaris L.). \\ Nafei. A.I.; A.M.H. Osman and Maha M. El.Zeny \\ Agron. Dept., Sugar Crops Res. Inst., Agric. Res. Center, Giza.
}

\begin{abstract}
Two field experiments were carried out during 2007/2008 and 2008/2009 seasons at Kafr El-Hammam Research Station, Sharkia Governorate to study the effect of planting densities and potassium fertilizer levels as well as their interaction on sugar beet productivity.

Increasing plant densities from 28000 to 42000 significantly increased root length, diameter, fresh weight/plants, sucrose\%, total soluble solids (TSS\%), phosphorus \% in roots as well as top, root and sugar yields (ton/fed) in both seasons. Plant density at 42000 plants/fed was the best treatment, where it gave the highest values on most traits under study.

Potassium fertilizer level at $36 \mathrm{Kg} \mathrm{K} \mathrm{K}_{2} \mathrm{O} / \mathrm{fed}$ gave significant increase root length, diameter, fresh weight/plant, total soluble solids\% and root yield in both seasons as well as sugar yield in the $1^{\text {st }}$ season only. In general, potassium at the level $36 \mathrm{~kg} \mathrm{~K} \mathrm{~K}_{2} \mathrm{O} / \mathrm{fed}$ was more effective than at $18 \mathrm{~kg}$ $\mathrm{K}_{2} \mathrm{O} / \mathrm{fed}$.

Interaction between plant densities and potassium fertilization levels do not gave any significant increase on all studied traits.

In general it can be concluded that sowing sugar beet with 42000 plants/fed and potassium fertilizer levels at $36 \mathrm{~kg} \mathrm{~K} \mathrm{~K}_{2} \mathrm{O} / \mathrm{fed}$ were the best treatment for maximizing sugar beet productivity in the newly reclaimed sandy soils under the environmental conditions of the present study.
\end{abstract}

\section{INTRODUCTION}

Sugar beet (Beta vulgaris L.) ranks the second important sugar crop after sugar cane, producing annually about $40 \%$ of sugar production all over the world. Despite the newness of sugar beet in Egypt, it has a large importance where, there are wide newly reclaimed soils at the East parts of Egypt, that could be cultivated with sugar beet without competition from other winter crops because of its tolerance to salinity and the ability to produce high yields of sugar under saline soil and water conditions, compared with most of other traditional winter crops. The total sugar beet cultivated area reached 260000 fed with an average tonnage of 19 tons i.e., the total sugar beet production in 4791000 tons of sugar that contributed to about $30 \%$ of total sugar production in Egypt (Annual Report of Sugar Crops Council, 2008). Sugar beet growth is largely influenced by the agronomic practices as crop stand and fertilization, especially in the newly reclaimed soils characterized with low content of organic matter and nutrients, which ultimately affect root 
Nafei. A.l. et al.

and sugar yields. It is known that too heavy population could restrict root growth to the point that very small beets will be lost during harvesting. On the contrary, in thin stand large sized beets with little quality i.e. more fibers, water and less sucrose content will be produced.

The optimum plant densities in sugar beet is very necessary to have high root yield with good quality. Laurer (1995) compared plant densities of $37100,61800,86500$, and 111200 plants/ha and found that sucrose content increased by $5 \mathrm{~g} / \mathrm{kg}$ as plant densities increased from 37000 to 111200 plants/ha. Kemp et al. (1996) sowing 60000, 80000, 100000, 120000 and 140000 plants/ha and found that maximum root fresh weight was obtained at 60000 plants/ha, maximum sugar yield at 80000 plants/ha and juice purity ranged from $89 \%$ at 140000 plants/ha to $82 \%$ at 60000 plants/ha. Arita et al. (1999) planted sugar beet cultivars sown in rows 50 or $60 \mathrm{~cm}$ apart with 18, 21 or $24 \mathrm{~cm}$ between plants in the row. They found that with $50 \mathrm{~cm}$ between rows and $24 \mathrm{~cm}$ between plants in the row gave average root and sugar yields 55.6 and 10.02 t/ha, respectively. Caliskan et al. (1998) reported that the highest root and sugar yields (73.00 and $12.21 \mathrm{t} / \mathrm{ha})$, respectively were obtained with $30 \mathrm{~cm}$ between spacing. Nassar (2001) found that increasing plant densities from 33600 up to 70000 planst/fed increased sucrose and purity\% and application of 42000 plants/fed produced the highest root and sugar yields. Sogut and Aroglu (2004) showed that sugar beet at 15 and 20 $\mathrm{cm}$ intra-row spacing produced higher root yield than 30 and $35 \mathrm{~cm}$ intra-row spacing between plants. El-Geddawy et al. (2006) found that increasing plant densities from 33600 up to 46666 plants/fed significantly increased purity\% and root as well as sugar yields. Ismail and Allam (2007) show that plant densities significantly affected root length and diameter, fresh weight/plants, as well as sodium \% and sucrose\% in both seasons in addition to sugar yield in the $2^{\text {nd }}$ one. They added that sowing sugar beet at 28000 and 42000 plants/fed gave the highest yield of root and sugar (tons/fed) and quality traits, respectively.

Potassium $(\mathrm{K})$ is a mobile element in the plant tissues. It has a role in physiological processes in the plant such as respiration, transpiration, translocation of sugars and carbohydrates, energy transformation and enzyme actions. Potassium is essentially element in plant life, promotes root growth and is conductive for higher sugar accumulation through its role in the photosynthesis process. Sugar beet yield and quality are greatly influenced by the applied K fertilization levels. El-Essawy (1996) showed that the K fertilization at $24 \mathrm{~kg} \mathrm{~K} 2 \mathrm{O} / \mathrm{fed}$ increased quality (sucrose\% and purity \%), as well as root and sugar yields of sugar beet plants. Ibrahim (1998) found that $48 \mathrm{~kg} \mathrm{~K} \mathrm{~K}_{2} \mathrm{O} / \mathrm{fed}$ significantly increased values of root length, diameter and fresh weight/plants, sucrose and purity\% as well as root and sugar yields (tons/fed). El-Shafai (2000) obtained that high root fresh weight, sugar yield (tons/fed) and sucrose\% were recorded from increasing $\mathrm{K}$ level up to $48 \mathrm{~kg}$ $\mathrm{K}_{2} \mathrm{O} / \mathrm{fed}$ while root yield and purity did not affect. Ismail et al. (2002) found that a significant increase in root fresh weight/plants, sucrose $\%$, purity $\%$, root and sugar yields were obtained from application of $24 \mathrm{~kg} \mathrm{~K} \mathrm{~K}_{2} \mathrm{O} / \mathrm{fed}$ with one spray of potassien compound. Ismail and Abo El-Ghait (2004) obtained highly root length, sucrose\%, root and sugar yields at $\mathrm{K}$ level up to $48 \mathrm{~kg} \mathrm{~K} \mathrm{~K}_{2} \mathrm{O} / \mathrm{fed}$. 
Shafika and El- Masry (2006) found that decreasing soil K fertilizer from 24 to12 $\mathrm{Kg} \mathrm{K} \mathrm{K}_{2} \mathrm{O} / \mathrm{fed}$ gave an obvious reduction in root diameter, length, fresh weight/plants and yields of root and sugar as well as root impurities content (K, Na and a-amino-N), while purity\% was increased. Ismail and Allam (2007) show that Potassium level significantly affected root length, root diameter, root fresh weight, root yield, sugar yield, alfa-amino nitrogen content and sucrose $\%$ in both seasons, while potassium content and purity\% were significantly influenced by potassium level only in the $2^{\text {nd }}$ season. The aim of the present work was to find out the optimal $\mathrm{K}$ levels required for sugar beet sown in sandy reclaimed soil at different plant densities to obtain the maximum yield and quality of sugar beet.

\section{MATERIALS AND METHODS}

Two field trials were carried out at Kafr El-Hammam Research Station, Sharkia Governorate during 2007/2008 and 2008/2009 seasons, to study the effect of plant densities and potassium fertilizer levels as well as their interactions on growth, yield and quality of sugar beet. seeds of a multigerm sugar beet variety (Sultan) were planted on 15 November in both seasons. The experimental design was a split-plot design with four replication, three plant densities, 28000 plants/fed [on ridges in $50 \mathrm{~cm}$ width and $30 \mathrm{~cm}$ between hills)], 33600 plants/fed [on ridges in $50 \mathrm{~cm}$ width and 25 $\mathrm{cm}$ between hills)] and 42000 plant/fed [on ridges in $50 \mathrm{~cm}$ width and $20 \mathrm{~cm}$ between hills)] respectively, were allocated in the main plots and three potassium fertilizer levels i.e. 0,18 and $36 \mathrm{~kg} \mathrm{~K} 2 \mathrm{O} / \mathrm{fed}$ ), respectively were randomly allotted in the sub-plots, each sub plot was $14 \mathrm{~m}^{2}$ (7 meters in length $\times 2$ meters in width) thus, the area of the plot 1/300 fed. Nitrogen fertilizer levels at the rate of $120 \mathrm{~kg} \mathrm{~N} / \mathrm{fed}$ was applied in four equal portions, the first was applied after thinning and 15 days between the other. The source of nitrogen fertilizer level was mineral fertilizer, in the form of ammonium nitrate $(33.5 \%)$. Super phosphate calcium $\left(15.5 \% \mathrm{P}_{2} \mathrm{O}_{5}\right)$ at the rate of $30 \mathrm{~kg} \mathrm{P} \mathrm{P}_{2} \mathrm{O}_{5} / \mathrm{fed}$ was added during land preparation. Potassium fertilizer levels were applied in four equal portions with nitrogen fertilizer in the form of potassium sulfate $\left(48 \% \mathrm{~K}_{2} \mathrm{O}\right)$. Manual planting was achieved in hills with approximately 3-4 seeds per hill and then plants were thinned at the fourth leaves stage (after 45 days from sowing) to obtain one plant per hill. Before soil preparation, soil samples were taken at a depth of $30-50 \mathrm{~cm}$ from different experimental sites, to determine physical and chemical properties of soil according to Piper, 1950 in Table 1.

Table 1: Physical and Chemical analysis of the experimental soil (as an averages of the two seasons).

\begin{tabular}{|c|c|c|c|c|c|c|c|c|c|}
\hline \multicolumn{3}{|c|}{ Particle size } & \multicolumn{2}{|c|}{ Soil textural } & \multirow[b]{2}{*}{ E.C. ds/m } & \multirow[b]{2}{*}{$\begin{array}{c}\text { Soil pH } \\
(1: 2.5)\end{array}$} & \multirow{2}{*}{\multicolumn{2}{|c|}{$\begin{array}{c}\text { Organic } \\
\text { matter \% }\end{array}$}} & \multirow[b]{2}{*}{$\begin{array}{c}\mathrm{CaCO}_{3} \\
\%\end{array}$} \\
\hline $\begin{array}{c}\text { Sand } \\
\%\end{array}$ & $\begin{array}{c}\text { Silt } \\
\%\end{array}$ & $\begin{array}{c}\text { Clay } \\
\%\end{array}$ & \multirow{2}{*}{\multicolumn{2}{|c|}{$\begin{array}{l}\text { Sand silty } \\
\text { loam }\end{array}$}} & & & & & \\
\hline 59.7 & 25.3 & 15.0 & & & 0.90 & 7.2 & & & 30.8 \\
\hline \multicolumn{4}{|c|}{ Soluble Cations (meq/L) } & \multicolumn{3}{|c|}{ Soluble anions(meq/L) } & \multicolumn{3}{|c|}{ available contents (ppm) } \\
\hline $\begin{array}{l}\mathrm{Ca}^{++} \\
2.03\end{array}$ & $\begin{array}{c}\mathbf{M g}^{++} \\
3.02\end{array}$ & $\begin{array}{l}\mathrm{Na}^{+} \\
4.24\end{array}$ & $\begin{array}{c}\mathbf{K}^{+} \\
0.15\end{array}$ & $\begin{array}{l}\mathrm{CO}_{3}^{--} \\
0.15\end{array}$ & $\begin{array}{c}\mathrm{HCO}_{3}^{-} \\
0.11\end{array}$ & $\begin{array}{l}\mathrm{SO}_{4}^{--} \\
3.27\end{array}$ & $\begin{array}{c}\mathbf{N} \\
17.9\end{array}$ & $\begin{array}{c}\mathbf{P} \\
20.2\end{array}$ & $\begin{array}{c}\mathbf{K} \\
56.3\end{array}$ \\
\hline
\end{tabular}


Nafei. A.l. et al.

Plants were harvested when the outside leaves of these plants turned yellow (after 210 days from sowing). At harvest, ten sugar beet plants were taken at random from each plot to estimate the following characters i.e. root length $(\mathrm{cm})$, root diameter $(\mathrm{cm})$, root fresh weight $(\mathrm{g} / \mathrm{plants})$, thereafter, roots and tops were separated and each was weighted in $\mathrm{kg}$, then after, it was converted to estimate root and top yields (ton/fed). Sugar yield (ton/fed) was calculated by multiplying root yield by sucrose $\%$, total soluble solids of roots (TSS\%), which was determined in fresh root by using hand refractometer. Sucrose\% was estimated polarimetrically on a lead acetate extract of fresh macerated roots according to Le-Docte (1927). Juice purity\% was calculated by dividing sucrose\% / TSS\% according to the method of (Carruthers et al., 1962). Some macro-elements ( $\mathrm{N}, \mathrm{P}$ and $\mathrm{K} \mathrm{g} / 100 \mathrm{~g}$ beet) were determined according to the method described by A.O.A.C. (1988).

Statistical analysis: The proper statistical analysis of the recorded data was carried out according to Gomez and Gomez (1984). The differences between means of the treatments were compared using the least significant difference (LSD) at $5 \%$ level.

\section{RESULTS AND DISCUSSION}

\section{A.1. Effect of plant density on top, root and sugar yield (tons/fed) of} sugar beet crop during 2007/2008 and 2008/2009 seasons.

Data in Table 2 reveal that the effect of plant densities namely 28000 , 33600 and 42000 plants/fed on top, root and sugar yield (tons/fed) of sugar beet plant. Significantly differences in top, root and sugar yield (tons/fed) as affect by plant densities in both seasons. The maximum yields of top, root and sugar (tons/fed) were obtained at 42000 plants/fed were 16.42, 35.35 and 5.72 in the $1^{\text {st }}$ season and $17.91,38.53$ and 6.40 in the $2^{\text {nd }}$ season, respectively, as compared with other plant densities Similar observations were obtained by Sogut and Aroglu (2004), El-Geddawy et al. (2006) and Ismail and Allam (2007).

Table 2: Effect of plant densities on top, root and sugar yield (tons/fed) and nitrogen, phosphorus and potassium \% of sugar beet roots during $2007 / 2008$ and $2008 / 2009$ seasons

\begin{tabular}{|c|c|c|c|c|c|c|}
\hline \multicolumn{7}{|c|}{$2007 / 2008$} \\
\hline $\begin{array}{c}\text { Plant } \\
\text { densities }\end{array}$ & $\begin{array}{l}\text { Top yield } \\
\text { (tons/fed) }\end{array}$ & $\begin{array}{l}\text { Root yield } \\
\text { (tons/fed) }\end{array}$ & \begin{tabular}{|c|}
$\begin{array}{c}\text { Sugar yield } \\
\text { (tons/fed) }\end{array}$ \\
\end{tabular} & $\begin{array}{l}\mathbf{N} \\
\%\end{array}$ & $\begin{array}{l}\mathbf{P} \\
\% \\
\end{array}$ & $\begin{array}{l}\mathbf{K} \\
\% \\
\end{array}$ \\
\hline 28000 & 15.10 & 31.55 & 4.53 & 1.079 & 0.387 & 1.073 \\
\hline 33600 & 15.81 & 33.23 & 5.05 & 1.093 & 0.399 & 1.074 \\
\hline 42000 & 16.42 & 35.35 & 5.72 & 1.120 & 0.460 & 1.101 \\
\hline F. Test & * & * & * & NS & * & NS \\
\hline LSD at $5 \%$ & 0.81 & 1.42 & 0.24 & - & 0.03 & - \\
\hline \multicolumn{7}{|c|}{$2008 / 2009$} \\
\hline 28000 & 17.26 & 37.28 & 5.67 & 1.073 & 0.392 & 1.079 \\
\hline 33600 & 17.84 & 35.65 & 6.08 & 1.070 & 0.434 & 1.093 \\
\hline 42000 & 17.91 & 38.53 & 6.40 & 1.106 & 0.453 & 1.119 \\
\hline F. Test & * & * & * & NS & * & NS \\
\hline LSD at $5 \%$ & 0.55 & 1.15 & 0.32 & - & 0.05 & - \\
\hline
\end{tabular}


A.2. Effect of plant density on macro-elements ( $\mathrm{N}, \mathrm{P}$ and $\mathrm{K} \mathrm{g} / 100 \mathrm{~g}$ beet) of sugar beet roots during 2007/2008 and 2008/2009 seasons.

Minerals imparticular potassium disturbs crystallization during sugar processing and thus affects the sugar output and its purity. Data in Table 2 show that the effect of plant densities on nitrogen, phosphorus and potassium\%. Generally, phosphorus\% was significant difference, the highest values obtained from 42000 plants/fed were $0.460,0.453$ in both seasons, respectively. This result is in agreement with that obtained by Ismail and Allam (2007).

B.1. Effect of potassium fertilizer levels $\left(\mathrm{K}_{2} \mathrm{O} / \mathrm{fed}\right)$ on top, root and sugar yield (tons/fed) of sugar beet crop during 2007/2008 and 2008/2009 seasons.

Data in Table 3 show that the effect of potassium fertilization levels namely 0,18 and $36 \mathrm{~kg} \mathrm{~K} \mathrm{~K}_{2} \mathrm{O} / \mathrm{fed}$ on top, root and sugar yield (tons/fed) of sugar beet plant. It is notice that increase potassium fertilization levels up to $36 \mathrm{~kg} \mathrm{~K} 2 \mathrm{O} / \mathrm{fed}$ significantly increase root yield of sugar beet in both seasons. Also, sugar yield in the $1^{\text {st }}$ season only and obtained the maximum values of top, root and sugar yield (tons/fed) were $16.74,35.45$ and 5.58 in the $1^{\text {st }}$ season and 18.27, 39.90 and 6.53 in the $2^{\text {nd }}$ season, respectively. These increase in root and sugar yields may be due to that potassium fertilizer is a mobile element in the plant tissues and it plays an important role in photosynthesis through carbohydrate metabolism, osmotic regulation, nitrogen uptake, protein synthesis, translocation of assimilates. These findings are in line with those observed by Ismail and Abo El-Ghait (2004), Shafika and El- Masry (2006) and Ismail and Allam (2007).

Table 3: Effect of potassium fertilizer levels on top, root and sugar yield (tons/fed) and nitrogen, phosphorus and potassium \% of sugar beet roots during $2007 / 2008$ and $2008 / 2009$ seasons

\begin{tabular}{|c|c|c|c|c|c|c|}
\hline \multicolumn{7}{|c|}{$2007 / 2008$} \\
\hline $\begin{array}{c}\text { Potassium fertilizer } \\
\text { levels }\left(\mathrm{K}_{2} \mathrm{O} / \mathrm{fed}\right)\end{array}$ & $\begin{array}{l}\text { Top yield } \\
\text { (tons/fed) }\end{array}$ & $\begin{array}{l}\text { Root yield } \\
\text { (tons/fed) }\end{array}$ & $\begin{array}{l}\text { Sugar yield } \\
\text { (tons/fed) }\end{array}$ & $\begin{array}{l}\mathbf{N} \\
\%\end{array}$ & $\begin{array}{l}\mathbf{P} \\
\%\end{array}$ & $\begin{array}{l}\mathbf{K} \\
\%\end{array}$ \\
\hline 0 & 14.23 & 29.45 & 4.35 & 1.091 & 0.410 & 1.073 \\
\hline 18 & 16.36 & 35.23 & 5.38 & 1.074 & 0.390 & 1.083 \\
\hline 36 & 16.74 & 35.45 & 5.58 & 1.127 & 0.446 & 1.092 \\
\hline F. Test & NS & * & * & NS & NS & NS \\
\hline LSD at $5 \%$ & - & 4.08 & 0.99 & - & - & - \\
\hline \multicolumn{7}{|c|}{$2008 / 2009$} \\
\hline 0 & 16.83 & 35.44 & 5.39 & 1.073 & 0.461 & 1.090 \\
\hline 18 & 17.91 & 39.12 & 6.23 & 1.083 & 0.423 & 1.074 \\
\hline 36 & 18.27 & 39.90 & 6.53 & 1.092 & 0.396 & 1.127 \\
\hline F. Test & NS & 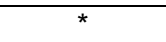 & NS & NS & NS & NS \\
\hline LSD at $5 \%$ & - & 3.44 & - & - & - & - \\
\hline
\end{tabular}

B.2. Effect of potassium fertilizer levels $\left(\mathrm{K}_{2} \mathrm{O} / \mathrm{fed}\right)$ on macro-elements $(\mathrm{N}$, $\mathrm{P}$ and $\mathrm{K} \mathrm{g} / \mathrm{100 \textrm {g }}$ beet) of sugar beet roots during 2007/2008 and 2008/2009 seasons.

Minerals imparticular potassium disturbs crystallization during sugar processing and thus affects the sugar output and its purity. Data in Table 3 
Nafei. A.l. et al.

show that the effect of potassium fertilization levels on nitrogen, phosphorus and potassium\%. It is also found that increase of potassium fertilizer level up to $36 \mathrm{~kg} \mathrm{~K} 2 \mathrm{O} / \mathrm{fed}$ did not cause any significant for nitrogen, phosphorus and potassium\% in both seasons. Our results are in accordance with that observed by Shafika and El- Masry (2006) and Ismail and Allam (2007).

C.1. Effect of plant densities on some root growth characters of sugar beet crop during 2007/2008 and 2008/2009 seasons:

Data in Table 4 indicate that the effect of plant densities at 28000 , 33600 and 42000 plants/fed on root length, diameter and fresh weight/plant in both seasons. It is notice that, increase plant densities up to 42000 plants/fed were significant increase on root length, diameter and fresh weight/plant in both seasons, which ranked first, followed by plant density was 33600 plants/fed and the last was 28000 plants/fed. Plant density at 42000 plants/fed gave the highest values were $27.40,15.72$ and 1178.3 in the $1^{\text {st }}$ season and 26.57, 17.18 and 1288.3 in the $2^{\text {nd }}$ season, respectively. These results are in accordance with those reported by Kemp et al. (1996) and Ismail and Allam (2007).

Table 4: Effect of plant densities on root characters and juice quality\% of sugar beet crop during 2007/2008 and 2008/2009 seasons

\begin{tabular}{|c|c|c|c|c|c|c|}
\hline \multicolumn{7}{|c|}{$2007 / 2008$} \\
\hline $\begin{array}{c}\text { Plant } \\
\text { densities }\end{array}$ & $\begin{array}{l}\text { Root } \\
\text { length } \\
(\mathrm{cm})\end{array}$ & $\begin{array}{l}\text { Root } \\
\text { diameter } \\
\text { (cm) }\end{array}$ & $\begin{array}{c}\text { Root fresh } \\
\text { weight } \\
\text { (g) }\end{array}$ & $\begin{array}{c}\text { Total Soluble } \\
\text { solids } \\
\text { (TSS\%) }\end{array}$ & $\begin{array}{c}\text { Sucrose } \\
\%\end{array}$ & $\begin{array}{c}\text { Purity } \\
\%\end{array}$ \\
\hline 28000 & 25.74 & 14.02 & 1051.7 & 19.10 & 14.35 & 75.24 \\
\hline 33600 & 26.49 & 14.77 & 1079.4 & 19.61 & 15.19 & 77.80 \\
\hline 42000 & 27.40 & 15.72 & 1178.3 & 20.24 & 16.16 & 80.10 \\
\hline F. Test & * & * & * & * & * & NS \\
\hline LSD at $5 \%$ & 0.63 & 0.63 & 47.39 & 0.44 & 0.64 & - \\
\hline \multicolumn{7}{|c|}{$2008 / 2009$} \\
\hline 28000 & 25.62 & 16.57 & 1242.5 & 20.80 & 15.15 & 72.91 \\
\hline 33600 & 26.26 & 17.12 & 1284.2 & 20.90 & 15.70 & 75.46 \\
\hline 42000 & 26.57 & 17.18 & 1288.3 & 21.44 & 16.47 & 76.48 \\
\hline F. Test & * & * & 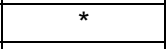 & * & * & NS \\
\hline LSD at $5 \%$ & 0.28 & 0.51 & 38.18 & 0.48 & 0.58 & - \\
\hline
\end{tabular}

\section{C.2. Effect of plant densities on root juice quality characters of sugar} beet crop during 2007/2008 and 2008/2009 seasons:

Sugar beet quality depends primarily on sugar content, the content of total soluble solids (TSS\%) and purity\%. Data in Table 4 revealed that plant densities at 42000 plants/fed gave significant increase for TSS\% and sucrose $\%$ comparing with plant densities 33600 and 28000 plants/fed. The highest mean values were 20.24 and 16.16 in the $1^{\text {st }}$ season and 21.44 and 16.47 in the $2^{\text {nd }}$ season, respectively. It is also found that plant densities from 28000 to 42000 plants/fed did not cause any significant for purity\% in both seasons. This finding could be attributed to increase root size and impurities content resulted to increase plant density up to 42000 plants/fed. These findings are in good agreement with those obtained by Laurer (1995) and Ismail and Allam (2007). 
D.1. Effect of potassium fertilizer levels $\left(\mathrm{K}_{2} \mathrm{O} / \mathrm{fed}\right)$ on some root growth characters of sugar beet crop during 2007/2008 and 2008/2009 seasons.

Data in Table 5 indicate that the effect of potassium fertilizer levels at 0 , 18 and $36 \mathrm{~kg} \mathrm{~K} \mathrm{~K}_{2} \mathrm{O} / \mathrm{fed}$ on root length, diameter and fresh weight/plant in both seasons. Increase potassium fertilizer levels up to $36 \mathrm{~kg} \mathrm{~K}$ O/fed significant increase in root length and diameter, as well as root fresh weight, which ranked first, followed by $18 \mathrm{~kg} \mathrm{~K} \mathrm{~K}_{2} \mathrm{O} / \mathrm{fed}$ and control (zero $\mathrm{K}_{2} \mathrm{O} / \mathrm{fed}$ ) in aforementioned characters. Potassium fertilizer level at the rate of $36 \mathrm{~kg}$ $\mathrm{K}_{2} \mathrm{O}$ /fed was the favorable which recorded the highest mean values were $27.58,15.76$ and 1181.56 in the $1^{\text {st }}$ season and 27.01, 17.73 and 1330.01 in the $2^{\text {nd }}$ season, respectively, Our results are in accordance with that observed by Ismail and Abo El-Ghait (2004), Shafika and El- Masry (2006) and Ismail and Allam (2007).

Table 5: Effect of potassium fertilizer levels on root characters and juice quality $\%$ of sugar beet roots during 2007/2008 and 2008/2009 seasons

\begin{tabular}{|c|c|c|c|c|c|c|}
\hline \multicolumn{7}{|c|}{$2007 / 2008$} \\
\hline $\begin{array}{l}\text { Potassium } \\
\text { fertilizer levels } \\
\left(\mathrm{K}_{2} \mathrm{O} / \mathrm{fed}\right)\end{array}$ & $\begin{array}{c}\text { Root } \\
\text { length } \\
\text { (cm) }\end{array}$ & $\begin{array}{l}\text { Root } \\
\text { diameter } \\
\text { (cm) }\end{array}$ & $\begin{array}{l}\text { Root fresh } \\
\text { weight }(\mathrm{g})\end{array}$ & $\left|\begin{array}{l}\text { Total soluble } \\
\text { solids (TSS\%) }\end{array}\right|$ & $\begin{array}{c}\text { Sucrose } \\
\%\end{array}$ & $\begin{array}{c}\text { Purity } \\
\%\end{array}$ \\
\hline 0 & 24.59 & 13.09 & 981.67 & 18.30 & 14.77 & 80.71 \\
\hline 18 & 27.47 & 15.66 & 1174.11 & 20.29 & 15.20 & 74.98 \\
\hline 36 & 27.58 & 15.76 & 1181.56 & 20.36 & 15.73 & 77.45 \\
\hline F. Test & * & * & * & * & NS & NS \\
\hline LSD at $5 \%$ & 2.43 & 1.82 & 136.02 & 1.61 & - & - \\
\hline \multicolumn{7}{|c|}{$2008 / 2009$} \\
\hline 0 & 24.89 & 15.75 & 1181.26 & 20.18 & 15.20 & 74.21 \\
\hline 18 & 26.54 & 17.38 & 1303.76 & 21.31 & 15.79 & 75.38 \\
\hline 36 & 27.01 & 17.73 & 1330.01 & 21.75 & 16.33 & 75.26 \\
\hline F. Test & * & * & * & ${ }^{*}$ & NS & NS \\
\hline LSD at $5 \%$ & 1.72 & 1.53 & 114.70 & 1.02 & - & - \\
\hline
\end{tabular}

D.2. Effect of potassium fertilizer levels $\left(\mathrm{K}_{2} \mathrm{O} / \mathrm{fed}\right)$ on root juice quality characters of sugar beet crop during 2007/2008 and 2008/2009 seasons:

Data in Table 5 indicate that the effect of potassium fertilizer levels on total soluble solids, sucrose and purity\% of sugar beet roots. The increase was significant for TSS\% in both seasons, the highest mean values were 20.36 and 21.75 in both seasons, respectively. It is also found that increased potassium fertilizer level from zero control treatment to $36 \mathrm{~kg} \mathrm{~K} \mathrm{~K}_{2} \mathrm{O} / \mathrm{fed}$ did not cause any significant for sucrose and purity\% in both seasons. Application of $36 \mathrm{~kg} \mathrm{~K} \mathrm{~K}_{2} \mathrm{O} / \mathrm{fed}$ increased mean values of these traits in both seasons. These finding are in the same line with those observed by Ismail and Abo El-Ghait (2004), Shafika and El- Masry (2006) and Ismail and Allam (2007). 


\section{REFERENCES}

A.O.A.C. (1988). Official methods of analysis. $14^{\text {th }}$ Ed., Association of Official Analytical Chemist, Alington, Virginia, USA.

Arita, T.; T. Kajiyama and M. Tezuka (1999). Effect of increased plant population by narrow row width $(50 \mathrm{~cm})$ on directly sown sugarbeet. Bull. Hokkaido Prefectural Agric. Exp. Stat., 77, 23-26. (c.f. Computer Research).

Caliskan, M.E; N. Isler; E. Gunel and M.B. Guler (1998). Effects of sowing date and row spacing on yield and quality of some sugarbeet (Beta vulgaris L.) cultivars in Hatay. Turkish J. Agric. and Forestry., 23, Supplement 5, 1155-1161. (c.f. Computer Research).

Carruthers, A.; J.F.T. Oldfield and H.J. Teague (1962). Methods for assessment of beet quality. $15^{\text {th }}$ Annual Technical Conference, British Sugar Corporation LTD. 36pp. (c.f.. The Sugar Beet Crop Book, 572573, $1^{\text {st }}$ Edition published by Chapman and Hall, Univ. Press, Cambridge, UK.).

El-Essawy, I.I. (1996). Effect of nitrogen, phosphorus and potassium fertilizers on yield and quality of sugar beet, J. Agric. Res., Tanta Univ., 22 (2): 270-278.

El-Geddawy, I.H., A.M.A. El-Shafai and N.B. Azzazy (2006). Yield and quality of some sugar beet varieties as affected by planting densities and nitrogen fertilization. J. Agric. Sci. Mansoura Univ., 31 (1): 43-54.

El-Shafai, A.M.A. (2000). Effect of nitrogen and potassium fertilization on yield and quality of sugar beet in Sohag. Egypt. J. Agric. Res., 78 (2): 759-767.

Gomez,K.A. and A.A. Gomez (1984): Statistical procedures for agricultural Research, Second Edition. John Willey and Sons, New York, pp.680.

Ibrahim, M.F.M. (1998). The effect of some fertilization elements on the yield and quality of sugar beet. Ph.D. Thesis, Fac. Agric., Moshtohor, Zagazig Univ., Egypt.

Ismail, A.M.A. and R. Abo El-Ghait (2004). Effect of balanced fertilization of NPK on yield and quality of sugar beet. Egypt. J. Agric. Res., 82 (2): 717-729.

Ismail, A.M.A.; Kh. A. Aboushady and S.M. Allam (2002). Response of some sugar beet varieties to methods of potassium application. Egypt. J. Appl. Sci., 17 (2): 86-101.

Ismail, A.M.A. and S.M. Allam (2007). Yield and technological traits of sugar beet as affected by planting density, phosphorus and potassium fertilization. The $3^{\text {rd }}$ Conf. Sustain. Agric. Develop., Fac. Agric., Fayoum Univ., 12-14 Nov., pp. 15-28.

Kemp, PD; AM. Khani and JP. Millner (1996). The effect of plant population and nitrogen level on sugar yield and juice purity of sugar beet (Beta vulgaris). Proc. Annl Conf. Agron. Soc. New Zealand., 24: 131-134. (c.f. Computer Research)

Laurer-JG (1995). Plant density and nitrogen rate effects on sugar beet yield and quality early in harvest. Agron. J. 87 (3): 586-591. 
Le docte, A. (1927). Commercial determination of sugar in beet root using the sacks. Le Docte proccess. Int. Sugar J., 29: 488-492.(c.f. Sugar beet Nut., April 1972 Appl. Sci. Pub. LTD, London, A.P.Draycott].

Nassar, A.M. (2001). Effect of plant densities on the productivity of some sugar beet varieties. J. Agric. Sci. Mansoura Univ., 26 (12): 7533-7546.

Piper, C.S. (1950). Soil and plant analysis. The Univ. of Adelaide, Australia.

Shafika, N. Moustafa and A.A. EL Masry (2006). Effect of nitrogen and potassium fertilization with or without spraying by iron combined with manganese on some physio- chemical properties, productivity and quality of sugar beet crop. Annals of Agric. Sci., Moshtohor 44 (4): 1431- 1446.

Sogut, T. and H. Aroglu (2004). plant densities and sowing date effects on sugar beet yield and quality. Agron. J. 96 (3): 215-218. (c.f. CAB Abstracts, record 73 of 649 ).

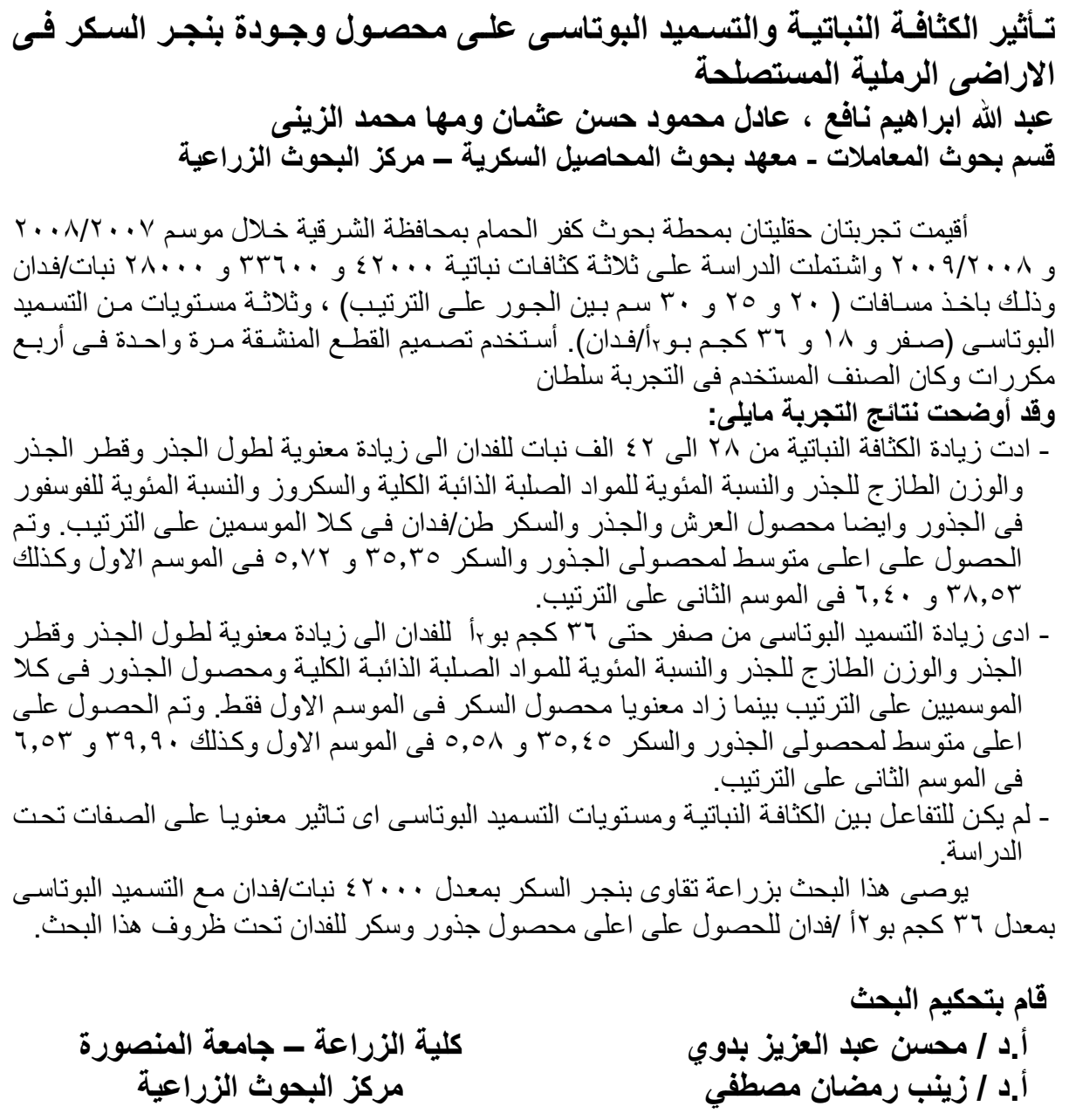

كلية الزراعة - جامعة المنصورة مركز البحوث الزراعية

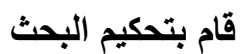

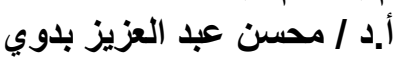 \\ أ.د أد / مينب رمضن عبد مصطفي لبوي
}

